Pak. j. sci. ind. res. Ser. B: biol. sci. 2018 61B(3) 158-164

\title{
Population Status and Distribution of Himalayan Brown Bear (Ursus arctos isabellinus) in Musk Deer National Park Neelum, Azad Jammu and Kashmir (Pakistan)
}

\author{
Liaqat Ali Khana, Riaz Aziz Minhasa, Muhammad Siddique Awana, \\ Khawaja Basharat Ahmad ${ }^{\mathrm{a}}$, Nuzhat Shafi ${ }^{\mathrm{a}}$, Usman Ali ${ }^{\mathrm{b} *}$ and Naeem Iftikhar \\ ${ }^{a}$ Department of Zoology, University of Azad Jammu and Kashmir, Muzaffarabad, Pakistan \\ ${ }^{b}$ Department of Zoology Mirpur University of Science and Technology (MUST), \\ Mirpur, 10250 Azad Jammu and Kashmir, Pakistan \\ 'Department of Wildlife and Fisheries, Government of Azad Jammu and Kashmir, Muzaffarabad, Pakistan
}

(received October 3, 2016; revised May 19, 2017; accepted June 22, 2017)

\begin{abstract}
The Himalayan brown bear (Ursus arctos isabellinus) is considered as 'Endangered' in Pakistan. However, a small population of this species still exists in northern Pakistan including Azad Jammu and Kashmir (AJK). A study was conducted to determine population status and distribution of Himalayan brown bear in Musk Deer National Park (MDNP), from April 2011 to September 2012. MDNP, covering an area of $528.16 \mathrm{~km}^{2}$, is situated in the extreme north of AJ\&K (upper Neelum Valley) about $155 \mathrm{~km}$ away from Muzaffarabad. Study area was divided into three zones (Phulawai, Sardari and Loser) and searched for brown bear signs and evidences. A total of 17 transect surveys were carried out to collect the data on current population status and distribution of Himalayan brown bear in the study area. In addition, questionnaires based surveys were carried out in the area to gather maximum information about this species. Based on direct and indirect signs collected, a total population of about 12 individuals with a population density of $0.42 \mathrm{bear} / \mathrm{km}^{2}$ was estimated in the MDNP with maximum $\left(0.45 \mathrm{bear} / \mathrm{km}^{2}\right)$ in Loser and minimum $\left(0.37 \mathrm{bear} / \mathrm{km}^{2}\right)$ in Phulawai zone. Altitudinal preference was recorded highest $\left(0.46 \mathrm{bear} / \mathrm{km}^{2}\right)$ at the elevation level of $>3000 \mathrm{~m}$ asl. For the proper management and conservation of Himalayan brown bear, more comprehensive study should be carried out throughout its potential habitat.
\end{abstract}

Keywords: population, distribution, Himalayan brown bear, Musk Deer National Park, Azad Jammu and Kashmir

\section{Introduction}

The brown bear (Ursus arctos isabellinus) is distributed in most of the Europe, Asia, North America, Middle East, and some parts of North Africa (Swenson et al., 2000; Servheen et al., 1999). In Asia, brown bear founds along Himalayas (from Pakistan to Bhutan), Afghanistan, Turkey, Iran, Central Asian mountains, Mongolia to Russia, and northern China, (Fig. 1) (Nawaz, 2007; Sathyakumar, 2001). Himalayan brown bears distributed in Jammu and Kashmir, northern Indian states including Uttaranchal and Himachal Pradesh (Sathyakumar, 2006), while in China, poorly defined populations are scattered in the northeast and west regions (Gong and Harris, 2006). Comparatively, Japan has a dense population though reliable data are lacking (Mano, 2006). In Pakistan, brown bear found in 7 healthy populations in the mountain ranges of Himalaya, Karakoram, and Hindu Kush including Gilgit Baltistan, Azad Jammu

*Author for correspondence;

E-mail: usman.zoology@must.edu.pk and Kashmir, and Khyber Pakhtunkhwa (KPK) (Nawaz, 2007). Bear population confined in patchy distribution in alpine meadows and sub-alpine zone of Deosai Plateau, Khunjrab National Park, Nanga Parbat, and Astore (Virk et al., 2003), nevertheless in western Himalaya, only Deosai Plateau has the stable population (Nawaz, 2007). In KPK, this species is distributed in the Kalam (Kohistan), Pallas Valley (Indus Kohistan) Kaghan Valley, and Chitral (Nawaz, 2007; Akbar, 2003; Arshad, 2003; Roberts, 1997).

In Azad Kashmir, brown bear is restricted to northern region including Machiara National Park, Gumote National Park, Shonther Valley, and Kel areas (Nawaz, 2007; Iftikhar, 2006). The Gurez Valley, mainly Musk Deer National Park, has good habitat conditions and likewise dense bear population (Nawaz, 2007). Besides Neelum Valley, they may also be found in the Leepa Valley (Jhelum Valley) and Haji Pir (district Bagh) areas (Iftikhar, 2006). Although, there is a large area with a potential habitat in Neelum Valley, but brown bears are 
restricted in certain pockets of the Valley, mainly in protected areas. Hunting pressure (Qamar et al., 2005), conflict with humans, habitat fragmentation (Nielsen et al., 2006; 2004) are important forces that reduce the bear population and thus distribution.

Various protected areas are established around the world that aim to support a viable population of brown bears, but only some of them are large enough to achieve this goal. Therefore, brown bear conservation must be integrated with many other human land-uses (Nielsen et al., 2006; Can and Togan, 2004; Herrero, 1994). Various countries established management guidelines intended to decrease human impacts on brown bears and their habitat, however many countries have limited or no bear management protocols and regulations (Zedrosser et al., 2001; Servheen et al., 1999). In Himalayan region, brown bear exist in low densities, their potential habitat range in India is estimated at $4,300 \mathrm{~km}^{2}$ and very little of this range is protected (Sathyakumar, 2001).

Although, brown bears are globally considered as Least Concerned (McLellan et al., 2008), however, they face many threats in Pakistan which cause its population to decline continuously and considered as 'endangered' (Sheikh and Molur, 2004). The largest population in Pakistan is estimated at 43 individuals existed in Deosai National Park, other six populations have less than 20 bears separately (Nawaz, 2007). A total of 20-25 bears were estimated in the north-eastern part of Neelum Valley (Nawaz, 2007), which is connected to Deosai National Park via Dudgai Top.

Main threats to the brown bear are increase in human population and thus increase in livestock, fuel wood and ethno-plant extraction, illegal trade of pelt and fat of bear, and climate change (Nawaz, 2007; Sheikh and Molur, 2004). Present study was designed to investigate the current status and distribution of brown bear in Musk Deer National Park (upper Neelum Valley) of Azad Jammu and Kashmir, Pakistan.

\section{Materials and Methods}

Study area: Musk Deer National Park (MDNP) is situated in the extreme northern part of AJ\&K (upper Neelum Valley) about $155 \mathrm{~km}$ away from Muzaffarabad. The area of Gurez Valley was declared as Musk Deer National Park in 2007 covering an area of $528.16 \mathrm{~km}^{2}$ (Sharda Forest Division) from Macchal to Kamri top. The park is bounded to the east and north east by occupied Kashmir through Line of Control (LoC) to the west and north west by Gilgit Baltistan (GB). Study area is geographically linked with Deosai National Park in GB (Fig. 1). Study area was divided in three zones i.e. Phulawai, Sardari and Loser based on geographic division in sub-valleys. Study zone Phulawai was further divided in study localities including Doga $\left(34^{\circ} 48.70 \mathrm{~N}\right.$, $\left.74^{\circ} 29.16 \mathrm{E}\right)$, Saonarr ( $\left.34^{\circ} 46.59 \mathrm{~N}, 74^{\circ} 36.85 \mathrm{E}\right)$ and Hanthi ( $\left.34^{\circ} 47.46 \mathrm{~N}, 74^{\circ} 29.12 \mathrm{E}\right)$. Sardari zone, was sub-divided in three localities, Helmet $\left(34^{\circ} 45.86 \mathrm{~N}\right.$, $\left.74^{\circ} 31.75 \mathrm{E}\right)$, Taobut $\left(34^{\circ} 43.27 \mathrm{~N}, 74^{\circ} 53.27 \mathrm{E}\right)$ and Karimabad ( $\left.34^{\circ} 44.21 \mathrm{~N}, 74^{\circ} 55.49 \mathrm{E}\right)$, while Loser zone has four study localities such as Gagai $\left(34^{\circ} 43.58 \mathrm{~N}\right.$, $74^{\circ}$ 52.26E), Rata Pani ( $\left.34^{\circ} 43.29 \mathrm{~N}, 7^{\circ} 56.49 \mathrm{E}\right)$, Dudhegai $\left(34^{\circ} 42.69 \mathrm{~N}, 74^{\circ} 46.95 \mathrm{E}\right)$ and Qamri $\left(34^{\circ}\right.$ $40.66 \mathrm{~N}, 74^{\circ} 50.12 \mathrm{E}$ ) (Fig. 1).

The study was conducted in MDNP, Gurez Valley, District Neelum, Azad Jammu and Kashmir (AJK) from April 2011 to December 2012. Line transect walks of varying length and width were carried out in 22 stands covering about $28.75 \mathrm{~km}^{2}$ area following Nawaz (2007) to gather data on distribution and population status of brown bear. 2-3 members of survey team traversed area parallel to each other by keeping a distance of 10 to $100 \mathrm{~m}$ apart, depending upon the terrain of the study area. Length of transect was measured using Garmin etrex (30x) GPS device, while average width was measured using Laser Range Finder Monocular Scan (TAC Vactor Optics; 8x30; $1200 \mathrm{~m}$ ). Population in a particular locality was estimated through measuring direct signs (fecal dropping, foot print, food remains, and sites of livestock depredation) and indirect reports of local peoples, hunters and shepherds. Based on the average daily home range/traveling distance (average $2.3 \mathrm{~km}$ for the daytime and $1.7 \mathrm{~km}$ for night) and daily activeness (6 h $40 \mathrm{~min}$ for day; $4 \mathrm{~h} 20 \mathrm{~min}$; $4 \mathrm{~h} 30 \mathrm{~min}$ for night) of the animal as given by the Gavrilov (2015), all evidences including direct and indirect within $\sim 4$ $\mathrm{km}$ area (average $24 \mathrm{~h}$ travelling range) were transformed into one animal (the least count), with exceptions where based on different foot prints (e.g., one small one large etc.) two animals were considered.

\section{Results and Discussion}

Distribution. Data revealed that Himalayan brown bear was distributed in different localities of Musk Deer National Park (MDNP). The direct and indirect evidences of bear were frequently found in all three zones of the study area (Phulawai, Sardari and Loser) (Table 1). 


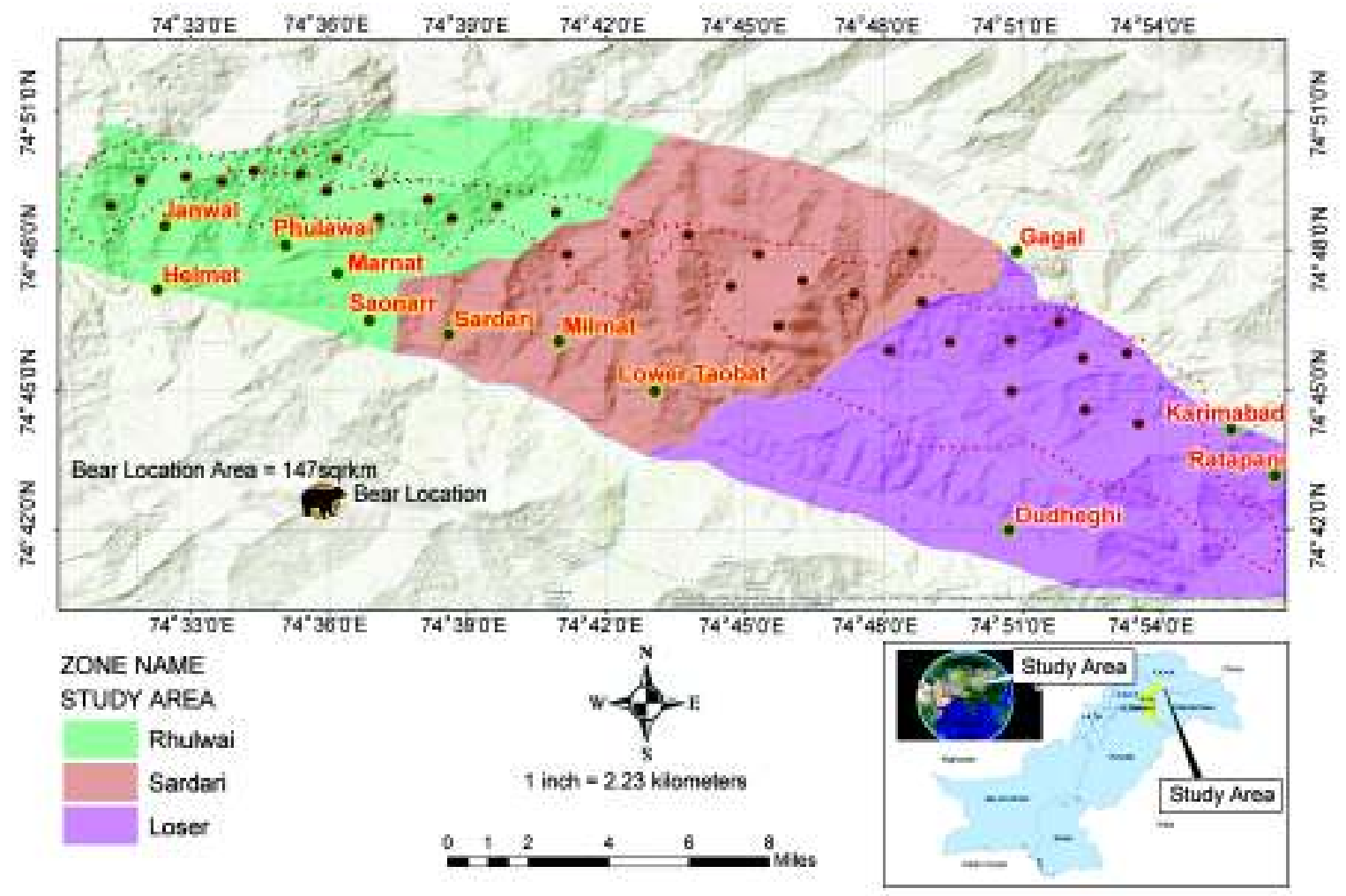

Fig. 1. Location map of study area (MDNP) showing different study zones.

Maximum bear population ( $\mathrm{n}=5$ ) was recorded in Losar zone, that is connected to Deosai National Park. Among three Zones, the maximum bear evidences $(\mathrm{n}=20)$ were found at Loser followed by Sardari $(\mathrm{n}=18)$ and Phulawai $(\mathrm{n}=12)$ (Table 1). Earlier studies conducted in Neelum Valley confirmed the distribution of brown bear in Gumote, Shonther, Gurez and valleys (Nawaz, 2007; Iftikhar, 2006; Qamar et al., 2005). The Gurez Valley branching off at Kel, having MDNP on the both sides of River Neelum, particularly has potential habitat of brown bear (Nawaz, 2007; Qamar et al., 2005), though, poaching and other human activities confined brown bear to certain area of the Valley (Qamar et al., 2005).

Population density. A total population of about 12 animals estimated in 17 field surveys was distributed over an area of $28.60 \mathrm{~km}^{2}$ in different localities of MDNP. Population density of the study area was recorded as 0.42 bear $/ \mathrm{km}^{2}$ (Table 2), maximum $\left(0.45 \mathrm{bear} / \mathrm{km}^{2}\right)$ at Loser zone followed by Sardari $\left(0.43 \mathrm{bear} / \mathrm{km}^{2}\right)$ while least $\left(0.37 \mathrm{bear} / \mathrm{km}^{2}\right)$ population density noted at Phulawai zone (Table 1).
Loser Zone has high population due to its potential habitat features. Most of the area consists upon a mixture of steep and gentle slopes, covered with a plenty of vegetation and far from human settlement. Vegetation cover not only provide hide to the bear but also has a plenty of food. Highest population density ( 0.63 bear/ $\mathrm{km}^{2}$ ) was recorded at Qamri locality of Loser area. This locality has direct connection to Deosai National Park through Qamri Top and there are strong evidences that brown bear is frequently visiting both sides of the Qamri Top. Fecal droppings $(\mathrm{n}=6)$, foot prints $(\mathrm{n}=5)$ and ground scratching $(\mathrm{n}=5)$ were recorded in this locality (Table 1$)$. Population density estimated based on direct evidences, indirect evidences were asked to confirm field observations. Direct evidences confined to different localities provide a complete picture on population estimation because brown bear remain active more than $40 \%$ in a day period, traveling $4 \mathrm{~km}$ per day in average. Speed is varying in different habitats and maximum speed is up to $6.5 \mathrm{~km} / \mathrm{h}$ in the grasslands to $0.3 \mathrm{~km} / \mathrm{h}$ in scrubland (Gavrilov, 2015). In forests, the average speed of bear recorded as $0.7 \mathrm{~km} / \mathrm{h}$ (Gavrilov, 2015). 
Altitudinal variation was also noted in bear population in the study area. Altitude of the study area was ranged between $2200 \mathrm{~m}$ and $3800 \mathrm{~m}$ asl, which was divided in three classes. Class I has altitude of less than $2500 \mathrm{~m}$, Class II ranged between $2500 \mathrm{~m}$ to $3000 \mathrm{~m}$ while Class III has an altitude of $>3000 \mathrm{~m}$ asl. Overall highest population density $\left(0.46\right.$ bear $\left./ \mathrm{km}^{2}\right)$ was recorded in
Class III, followed by Class I $\left(0.40\right.$ bear $\left./ \mathrm{km}^{2}\right)$ while least $\left(0.39\right.$ bear $\left./ \mathrm{km}^{2}\right)$ was noted in Class II (Fig. 2). In neighboring region i.e., India, the potential distribution range of Himalayan brown bear is about $36,800 \mathrm{~km}^{2}$ in the sub-alpine and alpine regions between 3000-5000 $\mathrm{m}$ in the Himalayas and Trans-Himalayan regions (Rathore, 2008). Himalayan brown bear preferred alpine

Table 1. Comparison of Himalayan brown bear population in different localities of MDNP during study period

\begin{tabular}{|c|c|c|c|c|c|c|c|c|}
\hline \multirow[t]{2}{*}{ Zone } & \multirow[t]{2}{*}{ Locality } & \multirow{2}{*}{$\begin{array}{l}\text { Mean } \\
\text { elevation }\end{array}$} & \multirow{2}{*}{$\begin{array}{l}\text { Area } \\
\text { surveyed } \\
\left(\mathrm{km}^{2}\right)\end{array}$} & \multirow{2}{*}{ Habitat conditions } & \multicolumn{2}{|c|}{ Evidence } & \multirow{2}{*}{$\begin{array}{l}\text { Estimated } \\
\text { population }\end{array}$} & \multirow{2}{*}{$\begin{array}{l}\text { Population } \\
\text { density } \\
\left.\text { (bear } / \mathrm{km}^{2}\right)\end{array}$} \\
\hline & & & & & Direct & Indirect & & \\
\hline \multirow[t]{4}{*}{ Phulawai } & Doga & 2480 & 2.9 & $\begin{array}{l}\text { Gentle slopes usually thickly vegetated with Pinus spp., } \\
\text { Taxus wallichiana, Arnebia benthamii, Valeriana } \\
\text { jatamansi, Berberis lycium. Agricultural activities, } \\
\text { including grass cutting, grazing etc are observed in this } \\
\text { locality. }\end{array}$ & $\begin{array}{l}\mathrm{FD}=4 \\
\mathrm{FP}=1 \\
\mathrm{GS}=2\end{array}$ & $\begin{array}{l}\mathrm{WW}=2 \\
\mathrm{Sh}=2 \\
\mathrm{LP}=1\end{array}$ & 1 & 0.34 \\
\hline & Saonarr & 2490 & 2.1 & $\begin{array}{l}\text { Thick vegetation of Pinus wallichiana, Pinus roxburghii, } \\
\text { Cedrus deodara, Saussurea lappa at lower altitude while } \\
\text { Berberis lycium and Betula utilis at higher gentle } \\
\text { slopes. Grazing is common along with terrace cultivation. }\end{array}$ & $\mathrm{FD}=2$ & $\begin{array}{l}\mathrm{WW}=2 . \\
\mathrm{Sh}=2\end{array}$ & 1 & 0.48 \\
\hline & Hanthi & 2540 & 3.2 & $\begin{array}{l}\text { Herbal blend includes Aconitum heterophyllum, Angelica } \\
\text { cyclocarpa, Podophyllum hexandrum at higher slopes } \\
\text { while frequent terrace cultivation noted on lower areas. } \\
\text { Betula utilis, Pinus wallichiana, and Pinus roxburghii are } \\
\text { important tree species. }\end{array}$ & $\mathrm{FD}=4$ & $\begin{array}{l}\mathrm{WW}=3 \\
\mathrm{Sh}=2\end{array}$ & 1 & 0.31 \\
\hline & Total & & 8.2 & & & & 3 & 0.37 \\
\hline \multirow[t]{4}{*}{ Sardari } & Helmet & 2590 & 3.9 & $\begin{array}{l}\text { Gentle slopes covered with evergreen forests of Pinus } \\
\text { wallichiana and Pinus roxburghii. Cultivation observed } \\
\text { on both sides of river Neelum, upper altitudes has grazing } \\
\text { impacts. }\end{array}$ & $\mathrm{FD}=8$ & $\begin{array}{l}\mathrm{WW}=3 \\
\mathrm{Sh}=2 \\
\mathrm{LP}=1\end{array}$ & 2 & 0.51 \\
\hline & $\begin{array}{l}\text { Karim- } \\
\text { abad }\end{array}$ & 2530 & 2.6 & $\begin{array}{l}\text { Gentle and steep slopes covered with Pinus spp. Along } \\
\text { with Betula utilis, Saussurea lappa, Aconitum } \\
\text { heterophyllum and Berberis lycium at upper reaches. }\end{array}$ & $\mathrm{FD}=1$ & $\begin{array}{l}\mathrm{WW}=3 \\
\mathrm{Sh}=4 \\
\mathrm{LP}=2\end{array}$ & 1 & 0.38 \\
\hline & Taobut & 3280 & 2.8 & $\begin{array}{l}\text { Dense Pinus vegetation covered gentle slopes of area } \\
\text { where grazing and cultivation activities are prominent. }\end{array}$ & $\begin{array}{l}\mathrm{FD}=4 \\
\mathrm{GS}=2\end{array}$ & $\begin{array}{l}\mathrm{WW}=3 \\
\mathrm{Sh}=5 \\
\mathrm{LP}=3\end{array}$ & 1 & 0.36 \\
\hline & Total & & 9.3 & & & & 4 & 0.43 \\
\hline \multirow[t]{5}{*}{ Loser } & Gagai & 3330 & 2.1 & $\begin{array}{l}\text { Area having blend of Alpine and Sub alpine, Taxus } \\
\text { wallichiana, Arnebia benthamii, Valeriana jatamansi, } \\
\text { Berberis lycium and Betula utilis are important species. } \\
\text { Upper reaches are under heavy livestock grazing pressure, } \\
\text { both by local and nomads. }\end{array}$ & $\begin{array}{l}\mathrm{FD}=6 \\
\mathrm{FP}=10 \\
\mathrm{FR}=3 \\
\mathrm{GS}=6\end{array}$ & $\begin{array}{l}\mathrm{WW}=2, \\
\mathrm{Sh},=5 \\
\mathrm{LP}=3\end{array}$ & 1 & 0.48 \\
\hline & $\begin{array}{l}\text { Ratta } \\
\text { Pani }\end{array}$ & 2990 & 3 & $\begin{array}{l}\text { Steep slopes having main vegetation of Taxus } \\
\text { wallichiana, Valeriana jatamansi, Arnebia benthamii, } \\
\text { Aconitum heterophyllum, Berberis lycium and } \\
\text { Betula utilis }\end{array}$ & $\begin{array}{l}\mathrm{FD}=9 \\
\mathrm{FP}=7 \\
\mathrm{GS}=4\end{array}$ & $\begin{array}{l}\mathrm{WW}=4, \\
\mathrm{Sh}=5 \\
\mathrm{LP}=4\end{array}$ & 1 & 0.33 \\
\hline & Dudhegai & i 3450 & 2.8 & $\begin{array}{l}\text { Gentle slopes charactrized by dense covering of Taxus } \\
\text { wallichiana, Arnebia benthamii, Valeriana jatamansi, } \\
\text { Berberis lycium and Betula utilis. Seasonal heavy } \\
\text { livestock grazing pressure is noted. }\end{array}$ & $\begin{array}{l}\mathrm{FD}=5 \\
\mathrm{FP}=2 \\
\mathrm{GS}=2\end{array}$ & $\begin{array}{l}\mathrm{WW}=5 \\
\mathrm{Sh}=7 \\
\mathrm{LP}=4\end{array}$ & 1 & 0.36 \\
\hline & Qamri & 3380 & 3.2 & $\begin{array}{l}\text { Both steep and gentle slopes covered with mixed alpine } \\
\text { grasses and sub-alpine scrub. Area grazed heavily by } \\
\text { nomad livestock at spring and autumn season during } \\
\text { their travel to MDNP and vice versa. }\end{array}$ & $\begin{array}{l}\mathrm{FD}=6 \\
\mathrm{FP}=5 \\
\mathrm{GS}=5 \\
\mathrm{FR}=6\end{array}$ & $\begin{array}{l}\mathrm{WW}=6, \\
\mathrm{Sh}=8 \\
\mathrm{LP}=4\end{array}$ & 2 & 0.63 \\
\hline & Total & & 11.1 & & & & & 0.45 \\
\hline
\end{tabular}

FD = fecal droppings; FP = foot prints; FR = food remains; GS = ground scratching; WW = wildlife watcher; Sh = shepherd; $\mathrm{LP}=$ local people. 
meadows and subalpine scrub mostly. However, it may descend down in search of food and shelter in different seasons and circumstances. Results of present study corresponded with previous literature, such as Nawaz (2007), who reported 10-15 individuals in the same area. Most of this population was found distributed in the extreme northern portion of the study area, which is in the proximity of the Deosai National Park. Based on the findings of the present study and information collected earlier, it is inferred that these bears are still present and their population is almost stable in the area.

Among the three zones of the study area, the majority $(42 \%)$ of the bear population was found in Loser Zone $(n=5)$ followed by Sardari Zone $(n=4,33 \%)$ and Phulawai Zone $(n=3,25 \%)$. Losar and Sardari Zones are located on the northern part of the national park, bordering the Northern areas and the Indian-held Kashmir. These areas are potential habitats of brown bear outside the study area and bear movements are usually reported between the study area and these adjoining areas. Besides, these zones of the park have sparsely populated human settlements, with less disturbance for bear population. Population density of these bears varies with respect to habitats and favorable habitats have high population density (Seryodkin, 2006; Miller et al., 1997). They face high hunting pressure because of the medicinal value of body parts and fat (Qamar et al., 2005). Fragmentation enhances highly risk of mortality of brown bears because low home range and food coerce bear toward human settlements and intensify its conflict (Nielsen et al., 2006; 2004).

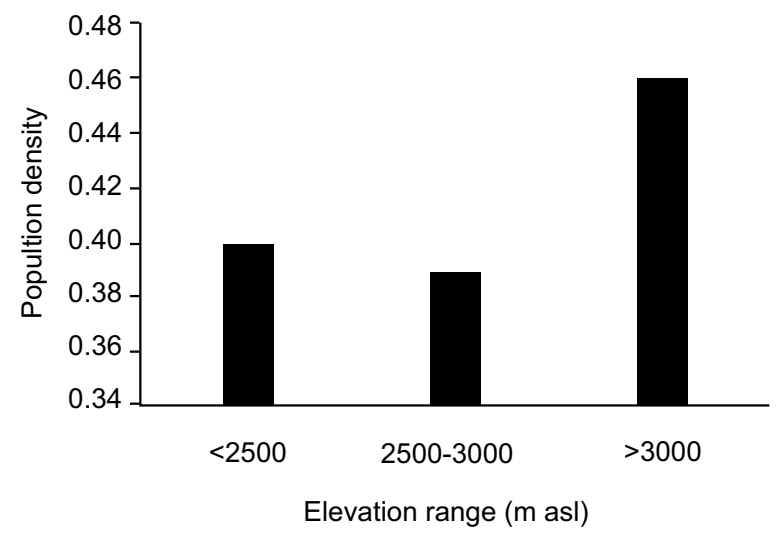

Fig. 2. Estimated populations of Brown bear at differen $t$ elevation ranges in MDNP during 2011-2012.
Population growth of such isolated and undersized populations are adversely affected even small numbers of members eliminated (Wakkinen and Kasworm, 2004); on the contrary, avoiding just a few deaths possibly halts a population decline (Garshelis et al., 2005; Wiegand et al., 1998).

Habitat fragmentation roots a great demographic and genetic risk to isolated populations (Proctor et al., 2004). Increasing human populations multiply this risk and speeds up the rate of habitat degradation in their vicinities (Nawaz, 2007; Can and Togan, 2004). However, if protection is provided, small populations could successfully be recuperated (USFWS, 2005). Reintroduction is an important tool that has restored numbers and geographic range in numerous locations in the U.S. and Western Europe (Clark et al., 2002; Servheen et al., 1994).

The reasons that the population of brown bears in the area could not increase in the area is more probably due to the huge human settlements. Rapid increase in human population, number of settlements and utilization of natural resources are the major contributing factors which adversely affect the brown bear population (Nawaz, 2007). These activities such as grazing, agriculture, fuel wood collection, hydroelectric developments etc. are well reported in literature (Waller and Servheen, 2005; Proctor et al., 2005; 2004). Various studies including Ali et al. (2016); Qamar et al. (2012); Qamar et al. (2010) and Ali et al. (2007) reported that potential habitats are disturbed by human being and over grazing, timber and fuel wood extraction, illegal collection of medicinal plants and illegal hunting are the major issues of the Neelum Valley. High demand of its fat for medicinal use is the severe risk to these animals in the area (Qamar et al., 2005).

\section{Conclusion}

In conclusion, Musk Deer National Parks harbors 12 Himalayan brown bears with a mean population density of $0.42 \mathrm{bear} / \mathrm{km}^{2}$. Study area has potential bear habitat characterizing different vegetation cover and ecological attributes. Bear population preferred higher altitudes ( $>3000 \mathrm{~m}$ asl). North-eastern boundary of MDNP is connected with Deosai National Park. Effective conservation efforts could support bear population up to selfsustaining level hence human interference should be reduced to maximum level in MDNP. This is an incipient study, and many of the scientific aspects of this precious threatened species are yet to be explored in the Neelum 
Valley. It is recommended that genetic diversity of brown bear could be investigated, that gives us the roots of Neelum Valley bear population. It is also suggested that the effects of illegal hunting (particularly intensity in chronological order) and habitat fragmentation may be studied.

\section{References}

Akbar, G. 2003. Zonification for the Valley Catchments of Bar Palas with Zone Specific Management Prescriptions. Palas Conservation and Development Project. WWF-Pakistan.

Ali, U., Minhas, R.A., Awan, M.S., Ahmed, K.B., Qamar, Z.Q., Dar, N.I. 2016. Human-grey wolf (Canis lupus Linnaeus, 1758) conflict in Shounther Valley, District Neelum, Azad Jammu and Kashmir, Pakistan. Pakistan Journal of Zoology, 48: 861868.

Ali, U., Ahmed, K.B. Awan, M.S., Ashraf, S., Basher, M., Awan, M.N. 2007. Current distribution and status of Himalayan ibex in upper Neelum Valley, District Neelum, Azad Jammu and Kashmir, Pakistan. Pakistan Journal of Biological Science, 10: 3150-3153.

Arshad, M. 2003. Review of approaches to species conservation in Pakistan. Palas Conservation and Development Project. WWF-Pakistan.

Can, Ö.E., Togan, I. 2004. Status and management of brown bears in Turkey. Ursus, 15: 48-53.

Clark, J.D., Huber, D., Servheen, C. 2002. Reintroducing bears: lessons and challenges. Ursus, 13: 153-163.

Garshelis, D.L., Gibeau, M.L., Herrero, S. 2005. Grizzly bear demographics in and around Banff National Park and Kananaskis Country, Alberta. Journal of Wildlife Management, 69: 277-297.

Gavrilov, G. 2015. Movement and activity pattern of a brown bear (Ursus arctos L.) tracked in Central Balkan Mountain, Bulgaria. ZooNotes, 70: 1-4.

Gong, J., Harris, R. 2006. The status of bears in China. In: Understanding Asian Bears to Secure their Future. pp. 96-101, Japan Bear Network, Ibaraki, Japan.

Herrero, S. 1994. The Canadian national parks and grizzly bear ecosystems: the need for interagency management. International Conference on Bear Research and Management, 9: 7-21.

Iftikhar, N. 2006. Wildlife of Azad Jammu and Kashmir. 69 pp., Al-Sheikh Press, Muzaffarabad, Azad Jammu and Kashmir, Pakistan.
Mano, T. 2006. The status of brown bears in Japan. In: Understanding Asian Bears to Secure their Future. Mano, T. (ed.), pp. 111-121, Japan Bear Network, Ibaraki, Japan.

McLellan, B.N., Servheen, C., Huber, D. 2008. Ursus arctos. In: IUCN Red List of Threatened Species, IUCN 2011, Version 2011.2. <www.iucnredlist. org $>$. Downloaded on 13 June 2015.

Miller, S.D., White, G.C., Sellers, R.A., Reynolds, H.V., Schoen, J.W., Titus, K., Barnes, V.G., Smith, J.R.B., Nelson, R.R., Ballard, W., Schwartz, C.C. 1997. Brown and black bear density estimation in Alaska using radio telemetry and replicated marker sight techniques. Wildlife Monographs, 133 pp.

Nawaz, M.A. 2007. Status of the brown bear in Pakistan. Ursus, 18: 89-100.

Nielsen, S.E., Stenhouse, G.B., Boyce, M.S. 2006. A habitat-based framework for grizzly bear conservation in Alberta. Biological Conservation, 130: 217-229.

Nielsen, S.E., Herrero, S., Boyce, M.S., Mace, R.D., Benn, B., Gibeau, M.L., Jevons, S. 2004. Modeling the spatial distribution of human-caused grizzly bear 12 mortalities in the Central Rockies ecosystem of Canada. Biological Conservation, 120: 101-113.

Proctor, M.F., McLellan, B.N., Strobeck, C., Barclay, R.M.R. 2005. Genetic analysis reveals demographic fragmentation of grizzly bears yielding vulnerably small populations. Proceedings of the Royal Society, 272: 2409-2416.

Proctor, M.F., Servheen, C., Miller, S.D., Kasworm, W.F., Wakkinen, W. L. 2004. A comparative analysis of management options for grizzly bear conservation in the U.S.-Canada trans-border area. Ursus, 15: 145-160.

Qamar, Z.Q., Ali, U., Minhas, R.A., Dar, N.I., Anwar, M. 2012. New distribution information on woolly flying squirrel (Eupetaurus cinereus Thomas, 1888) in Neelum Valley of Azad Jammu and Kashmir, Pakistan. Pakistan Journal of Zoology, 44: 13331342.

Qamar, Z.Q., Anwar, M., Dar, N.I., Ali, U. 2010. Ethnobotanical study of wild medicinal plants of Neelum Valley, Azad Jammu and Kashmir, Pakistan. Pakistan Journal of Wildlife, 1: 25-30.

Qamar, Z.Q., Awan, M.S., Maqsood, A., Shahid, M. 2005. Status of wild species and their management in Ghomat Game Reserve, District Muzaffarabad. Journal of Natural Science, 3-4: 100-108. 
Rathore, B.C. 2008. Ecology of brown bear (Ursus arctos) with Special Reference to Assessment of Human-brown bear Conflicts in Kugti Wildlife Sanctuary, Himachal Pradesh and Mitigation Strategies. Ph.D. Thesis, Saurashtra University.

Roberts, T.J. 1997. The Mammals of Pakistan (Revised edition), pp. 1-525, Oxford University Press Karachi, Pakistan.

Sathyakumar, S. 2006. The status of brown bears in India. In: Understanding Asian Bears to Secure their Future. pp. 7-11, Japan Bear Network, Ibaraki, Japan.

Sathyakumar, S. 2001. Status and management of Asiatic black bear and Himalayan brown bear in India. Ursus, 12: 21-30.

Servheen, C., Herrero, S., Peyton, B. 1999. Bears. Status survey and conservation action plan. IUCN/SSC Bear and Polar Bear Specialist Groups. IUCN, Gland, Switzerland and Cambridge, UK.

Servheen, C.W., Kasworm, W.F., Their, T. 1994. Transplanting grizzly bears as a management tool: Results from the Cabinet Mountains, Montana. Biological Conservation, 71: 261-268.

Seryodkin, I. 2006. The biology and conservation status of brown bears in the Russian Far East. In: Understanding Asian Bears to Secure their Future. pp. 79-85, Japan Bear Network, Ibaraki, Japan.

Sheikh, K.M., Molur, S. (eds.). 2004. Status and Red List of Pakistan's Mammals. Based on the Conservation Assessment and Management Plan. IUCN Pakistan, $312 \mathrm{pp}$.
Swenson, J.N., Gerstl, B.D., Zedrosser, A. 2000. Action Plan for the Conservation of the Brown Bear in Europe (Ursus arctos). Council of Europe, Strasbourg, France.

USFWS, 2005. Endangered and threatened wildlife and plants; Designating the greater Yellowstone ecosystem population of grizzly bears as a distinct population segment; removing the Yellowstone distinct population segment of grizzly 13 bears from the federal list of endangered and threatened wildlife. U.S. Fish and Wildlife Service. United States Federal Register, 70: 69854-69884.

Virk, D.A.T., Sheikh, D.M.K., Marwat, A.H. 2003. NASSD Background Paper: Biodiversity. IUCN Pakistan, Northern Areas Progamme, Gilgit. x+74 pp.

Wakkinen, W.L., Kasworm, W.F. 2004. Demographics and population trends of grizzly bears in the Cabinet-Yaak and Selkirk Ecosystems of British Columbia, Idaho, Montana, and Washington. Ursus, 15: $65-75$.

Waller, J.S., Servheen, C. 2005. Effects of transportation infrastructure on grizzly bears in Northwestern Montana. Journal of Wildlife Management, 69: 985-1000.

Wiegand, T., Naves, J., Stephan, T., Fernandez, A. 1998. Assessing the risk of extinction for the brown bear (Ursus arctos) in the Cordillera Cantabrica, Spain. Ecological Monographs, 68: 539-571.

Zedrosser, A.B., Dahle, J.E., Swenson, J.N., Gerstl, N. 2001. Status and management of the brown bear in Europe. Ursus, 12: 9-20. 